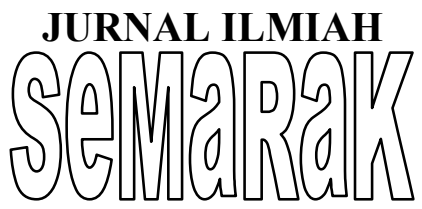

Jurnal Semarak,Vol. 1,No.3,Oktober 2018 , Hal (107-121)

@Prodi Manajemen Fakultas Ekonomi Universitas Pamulang

STRATEGI PENINGKATAN MOTIVASI DAN KOMPETENSI KARYAWAN

PT. SANJAYATAMA LESTARI DALAM MENGHADAPI PERSAINGAN

KINERJA KARYAWAN PERUSAHAAN LAIN

\title{
Jublina Oktora
}

\begin{abstract}
ABSTRAK
Kemampuan merencanakan dan mengelola perubahan yang bersifat kebijakan merupakan sebuah tuntutan dalam menghadapi persaingan-persaingan yang ada. Karyawan dituntut mampu menerima perubahan yang ada, memahami berbagai peraturan yang ada, merencanakan, melaksanakan serta mengevaluasi berbagai macam peraturan dan perubahan yang ada. Karyawan yang diharapkan saat ini merupakan karyawan yang mempunyai pengetahuan dan berwawasan ilmu pengetahuan dan teknologi.

Populasi penelitian adalah karyawan PT. Sanjayatama Lestari berjumlah 95 orang. Analisa menggunakan regresi linear berganda dengan nilai R sebesar 0.925. Memanfaatkan berbagai perubahan ilmu pengetahuan dan teknologi keahlian karyawan melalui motivasi $\left(\mathrm{X}_{1}\right)$, kompetensi $\left(\mathrm{X}_{2}\right)$ dan kinerja $(\mathrm{Y})$. Dengan demikian diharapkan kemampuan karyawan PT. Sanjayatama Lestari dapat maju dan bersaing dalam menghadapi persaingan perusahaan lainnya.
\end{abstract}

Dengan bantuan SPSS juga maka diperoleh bahwa motivasi berpengaruh sebesar 4,210 dan kompetensi berpengaruh sebesar 6,283.

Kata kunci: motivasi karyawan, kompetensi dan kinerja karyawan PT. Sanjayatama Lestari.

Keywords: leading sector, industry,competiveness and location quatient

\section{PENDAHULUAN}

\section{A. Latar Belakang}

Untuk mencari karyawan baru yang bekerja di PT. Sanjayatama Lestari biasanya diserahkan kepada Kordinator Sektor kemudian dibuatkan pengumuman kepada karyawannya secara langsung. Dengan kata lain, biasanya yang mendaftar menjadi calon karyawan baru di PT. Sanjayatama Lestari merupakan kerabat dari karyawan yang sudah bekerja di PT. Sanjayatama Lestari.

Namun sebelum karyawan baru masuk menjadi karyawan PT. Sanjayatama Lestari, mereka mengadakan test kemampuan dan test kesehatan agar mereka mengetahui bagaimana kondisi dan kemampuan calon karyawan tersebut.

$$
\text { Ketika kebutuhan fisiologis }
$$
(seperti makan dan minum) sudah terpenuhi maka manusia akan berusaha 


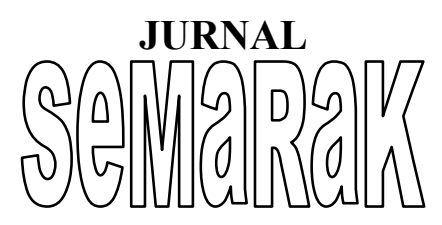

Semarak,Vol. 1, No.3,Oktober 2018, Hal (1-20)

@Prodi Manajemen Fakultas Ekonomi Universitas Pamulang

memenuhi aktualisasi diri. Motivasi merupakan dorongan agar karyawan PT. Sanjayatama Lestari mau melaksanakan tugasnya dengan baik dan benar.

Dalam bekerja diperlukan keahlian khusus atau kompetensi karyawan, oleh karena itu, perlu adanya pemberian pelatihan kompetensi karyawan agar pengembangan diri karyawan PT. Sanjayatama Lestari berkembang dan maju sehingga mampu bersaing dengan karyawan perusahaan lainnya.

PT. Sanjayatama Lestari merupakan sebuah perusahaan yang bergerak sebagai agency sumber daya manusia yang selanjutnya akan dilatih menjadi SBA (sahabat belanja anda) yang gunanya mempromosikan produk-produk Unilever. Oleh karena itu perlu adanya pelatihan-pelatihan terhadap pengenalan produk Unilever agar karyawan tersebut bisa memasarkan produk Unilever dengan baik, menjaga nama baik perusahaan dan dapat memajukan perusahaan.

\section{B. Identifikasi Permasalahan}

Menurut penjelasan yang penulis utarakan sebelumnya, diperolehlah beberapa persoalan yang mempengaruhi kinerja karyawan PT. Sanjayatama Lestari melalui pertanyaan berikut ini:
1. Benarkah motivasi mempengaruhi kinerja karyawan PT. Sanjayatama Lestari?

2. Benarkah kompetensi mempengaruhi kinerja karyawan PT. Sanjayatama Lestari?

\section{Pembatasan Masalah}

Penulis membatasi dengan hal :

1. Motivasi menurut Danang Sunyoto (2013 : 191) yaitu poses keinginan sebagai daya penggerak kemauan bekerja seseorang dan setiap motif mempunyai tujuan tertentu yang ingin dia gapai.

2. Uhar Suharsaputra (2013: 217) menyatakan kompetensi yaitu suatu karakter, sifat dari seorang untuk menghasilkan kinerja yang handal di dalam pengetahuan dan keahlian.

\section{Perumusan Masalah}

Perumusannya dapat di jabarkan seperti hal ini:

1. Benarkah motivasi karyawan mempengaruhi kinerja karyawan PT. Sanjayatama Lestari?

2. Benarkah kompetensi karyawan mempengaruhi kinerja karyawan PT. Sanjayatama Lestari?

E. Adanya Perolehan Dari Tujuan dan Manfaat Penelitian Yang Dilakukan 


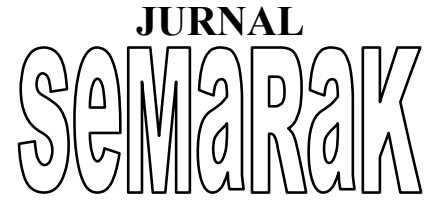

\section{Tujuannya}

Dari penjelasan uraian yang penulis lakukan, dapat diperoleh tujuannya yakni sebagai berikut :

a. Agar penulis dan pembaca mengetahui adanya pengaruh motivasi terhadap kinerja pada karyawan PT. Sanjayatama Lestari.

b. Agar penulis dan pembaca mengetahui adanya pengaruh kompetensi terhadap kinerja pada karyawan di PT. Sanjayatama Lestari.

\section{Manfaat Adanya Penelitian}

a. Kegunaan untuk teoritis :

1) Kegunaan untuk penulis dan pembaca yaitu dapat memperoleh penelitian baru mengenai kebijakan peningkatan sumber daya manusia khususnya dalam hal

2) motivasi dan kompetensi yang dapat berpengaruh terhadap kinerja karyawan PT. Sanjayatama Lestari.

3) Kegunaan untuk Universitas Pamulang yaitu bermanfaat agar dunia pendidikan dapat mengembangan ilmu manajemen baru dan dapat menjadi referensi penelitian mengenai motivasi dan kompetensi yang mempengaruhi kinerja karyawan.

b. Kegunaan praktis :

1) Sebagai evaluasi hasil uji coba mengenai kebijakan yang dilakukan pihak manajemen PT. Sanjayatama Lestari terkait dengan hal motivasi, kompetensi dan kinerja karyawan.

2) Merupakan sebuah informasi dan pengetahuan agar dapat meningkatkan kinerja karyawan PT. Sanjayatama Lestari.

3) Adanya pembuktian nyata bahwa terdapat motivasi serta kompetensi terhadap kinerja karyawan PT. Sanjayatama Lestari.

\section{F. Kerangka Berpikir}

Menurut Sudaryono (2014 : 205)

motivasi dikelompokkan menjadi dua motivasi yakni yang pertama yaitu dorongan internal adalah faktor yang berasal dari dalam diri pengikut kemudian dengan kesadaran tinggi melakukan sesuatu dan menjalankan pekerjaannya. Mereka melaksanakan kewajibannya dan tanggungjawabnya tanpa adanya kekerasan dan hasrat ingin di puji. Untuk seorang pekerja, bekerja merupakan suatu kewajiban dan hal penting yang harus dilakukannya. Yang kedua yaitu dorongan 
yang asalnya dari luar diri seseorang, misalnya keluarga, kekasih dan teman dekat. Setelah itu orang tersebut akan bekerja karena berharap mendapatkan gaji dan tunjangan yang dapat diberikan kepada orang lain dan juga dia pergunakan untuk keperluannya sendiri.

Kompetensi menurut Hollyforde dan Whiddett (2003 : 7) adalah perilaku yang individu tunjukkan ketika melakukan tugas pekerjaan yang relevan secara efektif dalam konteks suatu organisasi. Oleh sebab itu kompetensi diperlukan agar para pekerja dapat secara cekatan menyelesaikan pekerjaan yang diberikan oleh atasannya di PT. Sanjayatama Lestari.

\section{G. Hipotesis Dari Penelitian ini}

Sugiyono (2009 : 64) mengatakan bahwa hipotesis merupakan dugaan sementara yang ada terkait dengan berbagai masalah penelitian yang ada, dimana masalah penelitian dinyatakan dalam bentuk kalimat pertanyaan dan pernyataan. Bersifat sebagai dugaan karena jawaban yang pasti baru berdasarkan pada teori-teori yang ada, belum didasarkan pada fakta-fakta di lapangan yang diperoleh melalui pengumpulan data. Sesuai dengan berbagai masalah yang telah penulis teliti, diperoleh hipotesisnya yakni:

Ho $: \rho=0$ belum adanya hubungan yang saling berpengaruh antara motivasi karyawan PT. Sanjayatama Lestari dan kompetensi karyawan PT. Sanjayatama Lestari kepada kinerja karyawan di PT. Sanjayatama Lestari.

$>\mathrm{Ha}: \rho \neq 0 \quad$ sudah adanya hubungan yang saling terkait antara motivasi karyawan Pt. Sanjayatama Lestari dan kompetensi karyawan PT. Sanjayatama Lestari terhadap kinerja karyawan pada PT. Sanjayatama Lestari.

$>\rho=$ nilai korelasi dalam formulasi yang dihipotesiskan.

\section{LANDASAN TEORI PENELITIAN}

A. Arti Dari Manajemen Sumber Daya

\section{Manusia}

Menurut Marihot Tua (2012 : 1) yaitu human resource management is the activities undertaken to attack, develop, motivate and maintain a high performing workforce within the organization. Manajemen sumber daya manusia adalah aktivitas yang dilakukan merangsang, mengembangkan, memotivasi dan 


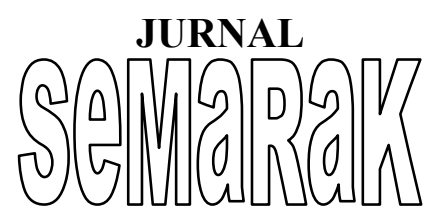

P-ISSN 2615-6849 E-ISSN 2622-3686

Semarak,Vol. 1, No.3,Oktober 2018, Hal (1-20)

@Prodi Manajemen Fakultas Ekonomi Universitas Pamulang

dari tingkat yang diinginkan dan organisasi.

\section{B. Kinerja}

\section{Pengertian Kinerja}

Selama karyawan bekerja di suatu perusahaan maka perlu diadakan evaluasi terhadap kinerjanya yang dilakukan oleh atasannya, oleh bagian personil dan oleh panitia khusus yang ditunjuk.

Menurut Murray Ainsworth (2002 : 3) menyatakan bahwa performance is means an outcome - a result. It is the end point of people, resources and certain environment being brought together, with intention of producing certain things, whether tangible product or less tangible service. To the extent that this interaction results in an outcome of the desired level and quality, at agreed cost levels, performance will be judged as satisfactory, good or excellent. To the extent that the outcome is disappointing for whatever reason, performance will be judged as poor or deficient. Artinya kinerja adalah hasil-hasilnya. Itu adalah hasil titik akhir dari orang, sumber daya dan lingkungan tertentu yang dibawa bersama-sama, dengan tujuan untuk memproduksi hal-hal tertentu, apakah produk nyata atau jasa kurang nyata. Sejauh interaksi ini menghasilkan hasil berkualitas, pada tingkat biaya yang disepakati, maka kinerja akan dinilai memuaskan, baik atau sangat baik. Jika hasilnya mengecewakan karena alasan apapun, maka kinerja akan dinilai miskin atau kekurangan.

\section{Penilaian Kinerja}

Penilaian kinerja adalah suatu evaluasi terhadap tingkat kinerja karyawan dibandingkan dengan standar kinerja yang sudah ditentukan, guna bahan pertimbangan dalam menentukan gaji, promosi, kompensasi, perlunya pelatihan atau pengembangan dan bahkan sampai untuk pemberhentian seseorang.

Penilaian kinerja ini mencakup kegiatan untuk memonitor pelaksanaan pekerjaan karyawan apakah sudah sesuai dengan keinginan perusahaan atau belum sesuai dengan keinginan organisasi. Dalam hal ini yang bertanggungjawab dalam penilaian tersebut adalah kepala bagian masing-masing.

Menurut Uhar Suharsaputra (2013 : 215) memberikan gambaran lebih rinci dan komprehensif tentang faktor-faktor yang berpengaruh terhadap kinerja, yaitu:

a. Variabel individu, meliputi kemampuan, keterampilan, 
JURNAL

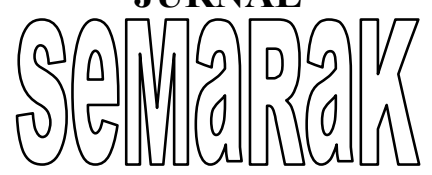

Semarak,Vol. 1, No.3,Oktober 2018, Hal (1-20)

@Prodi Manajemen Fakultas Ekonomi Universitas Pamulang

demografi (umur, asal usul, jenis kelamin).

b. Variabel organisasi, meliputi sumber daya, kepemimpinan, imbalan, struktur desain pekerjaan.

c. Variabel psikologis, meliputi persepsi, sikap, kepribadian, belajar dan motivasi.

\section{Motivasi}

\section{Pengertian Motivasi}

Manusia adalah makhluk sosial yang memiliki kebutuhan, perasaan, pikiran dan motivasi. Setiap manusia dalam melaksanakan suatu kegiatan pada dasarnya didorong oleh motivasi. Manusia bekerja keras dengan harapan dapat memenuhi kebutuhan dan keinginan dari hasil pekerjaannya. Motivasi dalam setiap organisasi dapat mempengaruhi tingkat pencapaian prestasi kerja pegawai yang berhubungan dengan suatu persyaratan pekerjaan.

Menurut Suparno Eko (2014 : 183) menyatakan bahwa motivasi adalah kekuatan yang ada dalam seseorang, yang mendorong prilakunya untuk melakukan tindakan. Besarnya intensitas kekuatan dari dalam diri seseorang untuk melakukan suatu tugas atau mencapai sasaran, memperlihatkan sejauh mana tingkat motivasinya.

\section{Hierarki kebutuhan menurut}

Abraham Maslow (2012 : 30)

a. Psychological needs (kebutuhan fisiologis) seperti makan, minum, gula, garam, protein, istirahat, seks dan lain-lain.

b. Safety needs (kebutuhan akan rasa aman) seperti kebutuhan akan keamanan, stabilitas, proteksi, struktur, hum, keteraturan, batas, bebas dari takut dan cemas.

c. Love needs/Belonging needs (kebutuhan akan cinta kasih) seperti kebutuhan kasih saying keluarga, teman, pasangan dan anak, selain itu juga kebutuhan untuk menjadi bagian dari kelompok masyarakat.

d. Esteem needs (kebutuhan penghargaan) seperti kebutuhan kekuatan, penguasaan, kompetensi, kepercayaan diri, kemandirian, kebutuhan penghargaan dari orang lain, status, ketenaran, dominasi, menjadi penting, kehormatan dan apresiasi.

e. Self actualization needs (kebutuhan aktualisasi diri) seperti kebutuhan orang untuk menjadi yang seharusnya sesuai dengan 


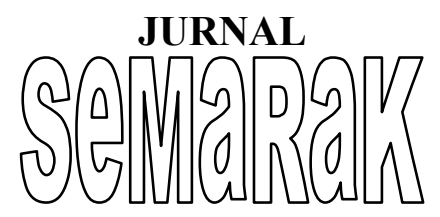

P-ISSN 2615-6849 E-ISSN 2622-3686

Semarak,Vol. 1, No.3,Oktober 2018, Hal (1-20)

@Prodi Manajemen Fakultas Ekonomi Universitas Pamulang potensinya, kebutuhan kreatif, realisasi diri, perkembangan diri, kebutuhan harkat kemanusiaan untuk mencapai tujuan, terus maju, menjadi lebih baik, kebutuhan berkaitan dengan pengetahuan dan pemahaman.

\section{Kompetensi}

Menurut Wina Sanjaya (2013 : 70) kompetensi adalah perpaduan dari pengetahuan, keterampilan, nilai dan sikap yang direfleksikan dalam kebiasaan berpikir dan bertindak.

Seseorang yang telah memiliki kompetensi dalam bidang tertentu, bukan hanya mengetahui tetapi juga dapat memahami dan menghayati bidang tersebut yang tercermin dalam pola perilaku sehari-hari. Dalam kompetensi sebagai tujuan, di dalamnya terdapat beberapa aspek yaitu:

1) Pengetahuan (Knowledge) yaitu kemampuan dalam bidang kognitif.

2) Pemahaman (Understanding) yaitu kedalaman pengetahuan yang dimiliki setiap individu.

3) Kemahiran (Skill) yaitu kemampuan individu untuk melaksanakan secara praktik tentang tugas atau pekerjaan yang dibebankan kepadanya.

4) Nilai (Value) yaitu norma-norma yang dianggap baik oleh setiap individu. Nilai inilah yang selanjutnya akan menuntun setiap individu dalam melaksanakan tugas-tugasnya.

5) Sikap (Attitude) yaitu pandangan individu terhadap sesuatu.

6) Minat (Interest) yaitu kecenderungan individu untuk melakukan sesuatu perbuatan.Minat adalah aspek yang dapat menentukan motivasi seseorang melakukan aktivitas tertentu.

\section{E. Penelitian Terdahulu}

Dalam melaksanakan penelitian tidak terlepas dari kajian penelitian sebelumnya sebagai landasan dan acuan arah dari penelitian ini.

Contoh penelitian terdahulu yang dipandang relevan dengan penelitian ini, yaitu sebagai berikut:

1) Penelitian Gusti Ayu Riska Riyanti, I Gede Adnyana Sudibya dengan judul pengaruh motivasi dan kompetensi terhadap kinerja 


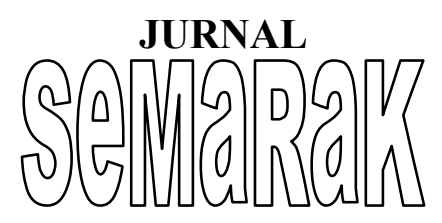

karyawan pada

Usadha.

2) Penelitian Ronald Listio dengan judul pengaruh kompetensi dan motivasi kerja terhadap kinerja karyawan PT. Aliannz Life Indonesia wilayah Jawa Barat.

3) Penelitian Linawati dengan judul pengaruh motivasi, kompetensi, keterampilan dan lingkungan kerja terhadap kinerja karyawan (studi pada PT. Herculon Carpet Semarang).

\section{III.METODOLOGI PENELITIAN}

\section{A. Ruang Lingkup Penelitian}

Dalam melakukan penelitian diperlukan suatu batasan yang dapat memudahkan penelitian agar menjadi lebih efektif dan efisien. Untuk itu dalam penelitian ini yang menjadi ruang lingkupnya antara lain :

\section{Tempat Penelitian}

Penelitian dilakukan di PT. Sanjayatama Lestari yang beralamat di Jl. Siaga 1 nomor 21, Pejaten Barat Pasar Minggu, Jakarta Selatan.

\section{Waktu Penelitian}

Dalam penelitian ini penulis membutuhkan waktu 3 bulan, yaitu mulai tanggal 10 Agustus 2018 sampai dengan
21 Oktober 2018. Dan untuk pembagian kuesioner dilaksanakan pada jam operasional kantor PT. Sanjayatama Lestari yaitu pada hari kerja, Senin sampai dengan Jumat, jam 08.00 WIB sampai dengan 17.00 WIB. Waktu ini juga digunakan untuk observasi pendahuluan, penyusunan surat izin, pengumpulan kepustakaan, penentuan sampel, instrumen penelitian, pengumpulan data, analisis data, penyebaran kuesioner, konsultasi, pengolahan data, pembuatan draft laporan, penyempurnaan laporan dan penyusunan akhir.

\section{Metode Penelitian}

Metode penelitian yang digunakan adalah metode survey dan wawancara dengan pendekatan kausal menggunakan skala Likert. Instrumen penelitian yang digunakan berbentuk kuesioner. Penggunaan kuesioner untuk mendapatkan data dari setiap variabel penelitian. Dalam penelitian ini terdapat 3 (tiga) variabel yang terdiri dari 2 (dua) variabel bebas yaitu motivasi, kompetensi dan 1 (satu) variabel terikat yaitu kinerja karyawan.

Dalam penelitian ini penulis mendeskripsikan data variabel dalam konstelasi penelitian yang digambarkan sebagai berikut: 
Gambar 3.1 Konstelasi

Penelitian

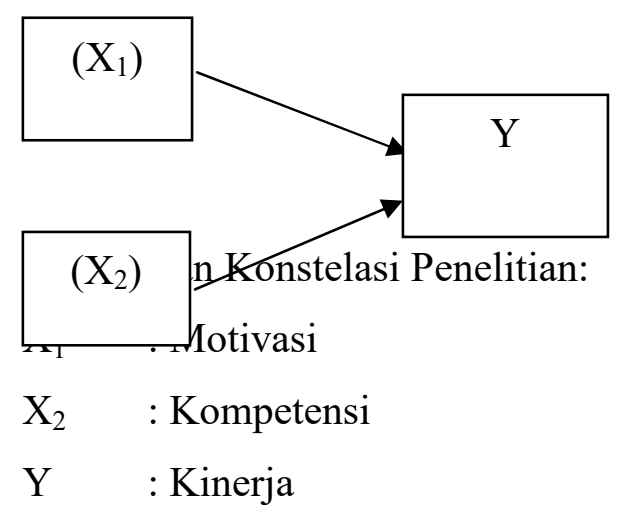

Konstelasi penelitian tersebut menggambarkan bagan pengaruh antar variabel yang peneliti teliti.

\section{B. Sensus}

Target penelitian yang ingin diteliti yaitu para karyawan PT. Sanjayatama Lestari yang berjumlah 95 karyawan.

\section{Sumber Data}

Sumber data yaitu keterangan yang benar dan nyata, yang dapat dijadikan kajian analisis atau kesimpulan dalam sebuah analisis atau kesimpulan dalam sebuah penelitian. Untuk memperoleh data dan informasi yang akurat dan objektif, maka dilakukan teknik pengumpulan data, sebagai berikut :

\section{Data Primer}

Data ini didapat dengan menggunakan kuesioner melalui studi lapangan.
Data primer dalam penelitian ini adalah data karyawan PT. Sanjayatama Lestari.

\section{Data Sekunder}

Data sekunder merupakan data yang diolah lebih lanjut sehingga menjadi bentuk-bentuk seperti tabel, grafik, diagram, dan sebagainya sehingga lebih informatif oleh pihak lain (Husein Umar, $2008: 84)$.

Data sekunder penelitian ini berasal dari olahan data karyawan PT. Sanjayatama Lestari.

\section{Metode Pengumpulan Data}

Dalam penulisan ini, diperlukan data dan berbagai informasi, untuk mendapatkannya maka penulis melakukan pengumpulan data tersebut dengan caracara sebagai berikut :

\section{Observasi}

Peneliti melakukan pengamatan secara langsung ke PT. Sanjayatama Lestari.

\section{Kuesioner}

Kuesioner merupakan teknik pengumpulan data yang dilakukan dengan cara memberi seperangkat pertanyaan atau pernyataan tertulis kepada para responden untuk dijawab. Kuesioner 


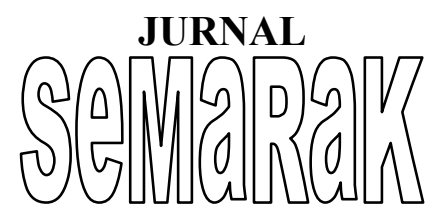

merupakan

Semarak,Vol. 1, No.3,Oktober 2018, Hal (1-20)

@Prodi Manajemen Fakultas Ekonomi Universitas Pamulang

pengumpulan data yang efisien bila peneliti tahu dengan pasti variabel yang akan diukur dan tahu apa yang bisa diharapkan dari para responden $(\mathrm{V}$. Wiratna Sujarweni, 2015 : 94).

\section{E. Metode Analisis Data}

Analisis data diartikan sebagai upaya data yang sudah tersedia kemudian diolah dengan statistik dan dapat digunakan untuk mejawab rumusan masalah dalam penelitian (V. Wiratna Sujarweni, 2015: 121).

Dalam penelitian ini, data yang terkumpul akan dianalisis untuk menghasilkan informasi yang bermanfaat. Dengan analisis data, peneliti dapat memberikan jawaban dari masalah yang dibahas dalam penelitian serta temuantemuan yang dapat dijadikan masukan.

\section{IV.PEMBAHASAN HASIL}

\section{PENELITIAN}

\section{A. Gambaran Umum Objek}

\section{Penelitian}

PT. Sanjayatama Lestari merupakan merupakan sebuah perusahaan yang bergerak sebagai agency sumber daya manusia yang selanjutnya akan dilatih menjadi sales promotion girl (SPG), namun PT. Sanjayatama Lestari bukan memakai nama SPG melainkan mereka memakai nama SBA (Sahabat Belanja Anda) khusus untuk produkproduk Unilever, yang kemudian mereka akan ditempatkan di Hypermarket, Supermarket dan MTI (toko independent). Hypermarket itu sendiri terdiri dari carefour, lottemart, giant, hero, hypermart dan foodmart. Kemudian supermarket itu terdiri dari superindo, Ramayana, tip top dan diamond. Selanjutnya MTI (toko independent) merupakan sebuah mini super atau sebuah toko yang mempunyai beberapa karyawan dan dikendalikan sendiri oleh pemiliknya.

Demi mencapainya promosi dan target penjualan Unilever, PT. Sanjayatama Lestari juga melatih general trade (GT) yang akan ditempatkan di sebuah toko yang ada di pasar.

1. Visi

Meningkatkan penjualan produk Unilever.

\section{Misi}

a. Berusaha menjual produk Unilever sebanyak-banyaknya.

b. Menjadi rekan yang utama bagi para konsumen produk Unilever.

c. Berusaha meningkatkan target penjualan produk Unilever.

\section{Karakteristik Responden}




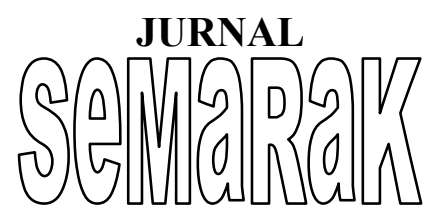

P-ISSN 2615-6849 E-ISSN 2622-3686

Semarak,Vol. 1, No.3,Oktober 2018, Hal (1-20)

@Prodi Manajemen Fakultas Ekonomi Universitas Pamulang
Data primer penelitian ini dikumpulkan dari 95 responden yang merupakan karyawan PT. Sanjayatama Lestari. Karakteristik responden dalam penelitian ini adalah berdasarkan jenis kelamin, umur, status pernikahan, jenis pekerjaan, dan lamanya sudah menjadi karyawan.

\section{B. Hasil Uji Instrumen}

\section{Hasil Uji Validitas}

\section{Reliabilitas}

Sebagai langkah awal, penulis ingin menguji valid atau tidaknya setiap pernyataan dalam kuesioner, dengan menggunakan uji validitas. Pengujian validitas dilakukan dengan menghitung koefisien korelasi antara setiap skor butir instrumen dengan skor total. Koefisien korelasi yang digunakan dalam penelitian ini adalah korelasi Product Moment, dimana dalam penghitungannya penulis menggunakan bantuan software IBM Statistical Package for Social Science (SPSS) versi.16 for Windows.

\section{Hasil Analisis Deskriptif}

Dengan menggunakan indikator maka diperoleh nilai dan kategori untuk kedua variabel penelitian sebagai berikut :

Tabel 4.1

Rata-rata Skor dan Kategori Variabel Penelitian

\begin{tabular}{|l|c|c|}
\hline \multicolumn{1}{|c|}{ Variabel } & $\begin{array}{c}\text { Rerata } \\
\text { skor }\end{array}$ & Kategori \\
\hline Motivasi & 3,19 & $\begin{array}{c}\text { Kadang- } \\
\text { kadang }\end{array}$ \\
\hline Kompetensi & 3,85 & $\begin{array}{c}\text { Kadang- } \\
\text { kadang }\end{array}$ \\
\hline
\end{tabular}

Sumber : hasil olah data primer, 2018

3. Hasil Uji Analisis Korelasi Pearson

Konsep dasar uji analisis korelasi bertujuan untuk mengetahui tingkat keeratan hubungan antar variabel yang dinyatakan dengan koefisien korelasi (r). Jenis hubungan antar variabel $\mathrm{X}$ dan $\mathrm{Y}$ dapat bersifat positif dan negatif.

Dasar pengambilan keputusan :

- Jika nilai Signifikansi $<0,05$, maka terdapat pengaruh yang signifikan

Jika nilai Signifikansi $>0,05$, maka pengaruh tidak signifikan

\section{Hasil Uji Koefisien Determinasi}

Tabel 4.2

Hasil Uji Koefisien Determinasi Model Summary

\begin{tabular}{|c|c|c|c|c|}
\hline Mode & $R$ & $R$ Square & $\begin{array}{l}\text { Adjusted } \\
R \text { Square }\end{array}$ & Std. Error of the Estimate \\
\hline 1 & &, 8566 & ,280 & 4,009 \\
\hline
\end{tabular}

\section{Sumber : hasil olah data primer, 2018}

Tabel di atas menjelaskan besarnya nilai korelasi/hubungan $(\mathrm{R})$ yaitu sebesar 0,925. Dari output tersebut 


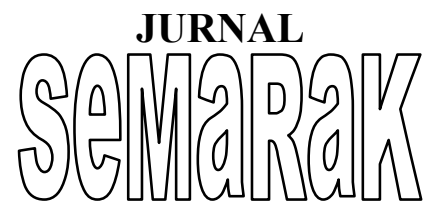

P-ISSN 2615-6849 E-ISSN 2622-3686

Semarak,Vol. 1, No.3,Oktober 2018, Hal (1-20)

@Prodi Manajemen Fakultas Ekonomi Universitas Pamulang

diperoleh koefisien determinasi $(R$ pengaruh motivasi dan kompetensi Square) sebesar 0,856 yang mengandung terhadap kinerja karyawan.

pengertian bahwa pengaruh variabel Hasil hipotesis dapat dirumuskan sebagai kinerja (Y) ditentukan oleh variabel berikut:

motivasi dan kompetensi. Sedangkan - Ho $: \rho=0$, tidak terdapat pengaruh sisanya 14,4\% ditentukan oleh faktor lain, yang signifikan antara motivasi dan seperti budaya organisasi, kompensasi dan kompetensi terhadap kinerja karyawan lingkungan kerja.

PT. Sanjayatama Lestari.

\section{Hasil Uji Regresi Linier}

Sederhana

Analisis regresi tidak hanya signifikan antara motivasi dan kompetensi sekedar menguji hubungan atau pengaruh dan arah hubungannya variabel bebas (X) terhadap variabel terikat (Y), tetapi juga dapat mengestimasi atau memprediksi seberapa besar perubahan variabel terikat ketika terjadi perubahan pada variabel bebas dengan melihat koefisien regresinya. Analisis regresi yang digunakan dalam penelitian ini adalah regresi linear sederhana, karena hanya terdapat dua variabel bebas yaitu motivasi dan kompetensi.

\section{Hasil Pengujian Hipotesis}

Uji $t$ dalam regresi linear sederhana digunakan untuk menguji signifikansi pengaruh variabel bebas terhadap variabel terikat secara parsial atau individual. Uji $t$ dalam penelitian ini digunakan untuk menguji signifikansi

terhadap kinerja karyawan PT. Sanjayatama Lestari.

\section{V.KESIMPULAN DAN SARAN}

\section{A. Kesimpulan}

Sesuai dengan tujuan penelitian dan hasil analisa, dapat diambil kesimpulan bahwa:

1. Variabel motivasi mempunyai pengaruh yang positif dan signifikan terhadap kinerja karyawan. Hal ini terlihat pada indikator seperti jenjang karir yang diberikan oleh PT. Sanjayatama Lestari yang dianggap dapat memotivasi para karyawan untuk bekerja sebaik mungkin sehingga karyawan mampu mencapai target yang diberikan oleh perusahaan.

2. Variabel kompetensi mempunyai pengaruh yang positif dan signifikan terhadap kinerja 


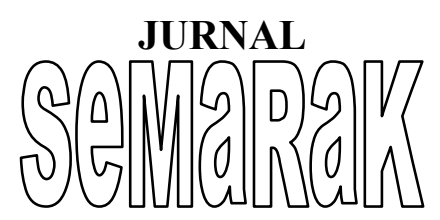

karyawan. Hal ini terlihat pada indikator seperti karyawan mampu menguasai bidang tugasnya, yang fungsinya membantu karyawan agar menyelesaikan pekerjaannya secara cepat dan akurat.

\section{B. Saran}

Berdasarkan pada hasil penelitian, maka dapat dibuat beberapa saran terhadap perusahaan, yaitu

1. Pemimpin hendaknya memberikan kepercayaan kepada karyawan agar karyawan lebih bertanggungjawab terhadap tugas yang diberikan.

2. Pemimpin seharusnya konsisten terhadap visi dan misi perusahaan sehingga para karyawan juga termotivasi untuk tetap konsisten.

3. Pemimpin sebaiknya memberikan penghargaan kepada karyawannya jika melakukan tugasnya dengan baik dan menguntungkan perusahaan.

4. Pemimpin sebaiknya memberikan pelatihan (training) kepada karyawan PT. Sanjayatama Lestari untuk menggunakan Bahasa Inggris karena visitor PT, Sanjayatama Lestari ada yang berasal dari luar negeri, sehingga komunikasi juga berjalan dengan baik.

5. Meskipun motivasi dan kompetensi berpengaruh positif dan signifikan terhadap kinerja karyawan, namun disarankan kepada penelitian berikutnya untuk meneliti pengaruh variabel lainnya seperti budaya organisasi, kompensasi dan lingkungan kerja di PT. Sanjayatama Lestari yang fungsinya agar demi meningkatkan kemajuan PT. Sanjayatama Lestari.

\section{DAFTAR PUSTAKA}

Ainsworth, Murray, Managing Performance, Managing People: Understanding and Improving Team Performance, Frenchs Forest: Pearson Education, 2002.

Eko, Suparno, Manajemen Pengembangan Sumber Daya Manusia, Jakarta: Ardadizya Jaya, 2014.

Ferdinand, Augustynd, Metode Penelitian Manajemen, Semarang: AGF Books, 2006.

K. Hoy, Wayne \& Cecil G. Miskel, Educational Administration Theory, Research and Practice, New York: Mc Graw Hill, 2005. 


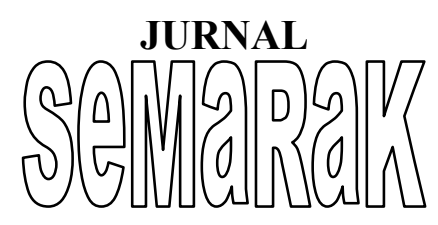

P-ISSN 2615-6849 E-ISSN 2622-3686

Semarak,Vol. 1, No.3,Oktober 2018, Hal (1-20)

(a)Prodi Manajemen Fakultas Ekonomi Universitas Pamulang
Keran, Kristina Nugi, Pengaruh Motivasi

Kerja, Kompetensi Dan Kompensasi

Terhadap Kinerja Karyawan di Yayasan

Bintang Timur Tanggerang, Universitas

Esa Unggul, 2012.

Khozin, Hierarki Kebutuhan Maslow

Dalam Perspektif Pendidikan Islam,

Yogyakarta: Interpena, 2012.

Listio, Ronald, Pengaruh Kompetensi Dan

Motivasi Kerja Terhadap Kinerja

Karyawan PT. Aliannz Life Indonesia

Wilayah Jawa Barat, Universitas

Komputer Indonesia Bandung, 2010.

Mangkunegara, Anwar Prabu, Manajemen

Sumber Daya Manusia Perusahaan,

Bandung: Remaja Rosdakarya, 2001.

Mulyasa, E., Manajemen Berbasis

Sekolah Konsep, Strategi dan

Implementasi, Bandung: PT.

Remaja Rosdakarya Offset, 2011.

Noe, A Raymond, Manajemen

Sumber Daya Manusia Mencapai

Keunggulan Bersaing, Jakarta:

Salemba Empat, 2013.

Pramono, Agus, Dian Triyani.

Pengaruh Kompensasi, Motivasi,

Lingkungan Kerja Dan

Kepemimpinan Terhadap Kinerja

Karyawan PT. Adi Mitra Pratama

Semarang, Jurnal dinamika

volume 1 nomor 5, 2010.
Putra, Nicko Permana, Pengaruh

Kepemimpinan, Motivasi,

Lingkungan Kerja Dan Disiplin

Kerja Terhadap Kinerja

Karyawan Pada PT. Indonesia

Power Semarang, Jurnal Indonesia

Power Semarang, 2013.

Riyanti Gusti Ayu Riska, I Gede

Adnyana Sudibya, Pengaruh

Motivasi Dan Kompetensi

Terhadap Kinerja Karyawan Pada RSU Dharma Usadha, (Fakultas

Ekonomi Universitas Udayana, 2012), h. 622.

Rosadi, Dodi, Pengaruh Kompensasi Dan Lingkungan Kerja Terhadap Motivasi Kerja Serta Dampaknya Pada Kinerja Pegawai di Pusat Pembinaan, Pendidikan Dan Pelatihan Peneliti-LIPI, Pusat Pembinaan, Pendidikan Dan Pelatihan Peneliti-LIPI, 2015.

Sanjaya, I Kadek Edy, Ayu Desi Indrawati. Pengaruh Kompetensi, Kompensasi Dan Lingkungan Kerja Terhadap Kinerja Karyawan Pada PT. Pande Agung Segara Dewata, Fakultas Ekonomi Universitas Udayana, 2013. 
JURNAL

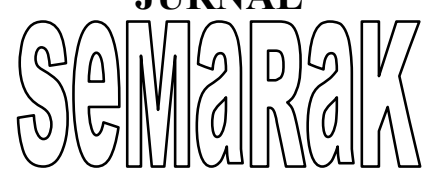

Semarak,Vol. 1, No.3,Oktober 2018, Hal (1-20)

@)Prodi Manajemen Fakultas Ekonomi Universitas Pamulang

Sanjaya, Wina, Strategi

Pembelajaran Berorientasi

Standar Proses Pendidikan,

Jakarta: Kencana Prenadamedia

Group, 2013.

Santoso, Singgih, Menggunakan

SPSS Untuk Statistik Parametrik,

Jakarta: Alex Media Komputindo, 2006.

Saptianingsih, Bayu, Pengaruh

Kompensasi, Motivasi Dan

Lingkungan Kerja Terhadap

Kinerja Karyawan Bagian

Produksi PT. Nyonya Meneer

Semarang, lib.unnes.ac.id, 2010.

Sekaran, Uma, Research Methods

For Business, Jakarta: Salemba

Empat, 2006.

Simanjuntak Friskha Dora, Ahmad

Calam. Pengaruh Kepemimpinan

Transformasional Dan Motivasi

Kerja Terhadap Kinerja

Karyawan PT. PLN (PERSERO)

Cabang Binjai Wilayah Sumatera

Utara, Jurnal SAINTIKOM Vol.

11 No.2, 2012.

Sugiyono. Metode Penelitian Administrasi, Bandung: Alfabeta, 2002.
Sugiyono. Metode Penelitian Bisnis Pendekatan Kuantitatif, Kualitatif dan $R \& D$, Bandung: Alfabeta CV, 2009.

Suharsaputra, Uhar. Administrasi Pendidikan, Bandung: PT. Refika Aditama, 2013.

Sunyoto, Danang, Manajemen Sumber Daya Manusia, Jakarta: CAPS, 2013. 